\title{
A.JOTE
}

African Journal of Teacher Education

ISSN 1916-7822. A Journal of Spread Corporation

Volume 10. No. 12021 Pages 325-345

\section{Adult Literacy Facilitators' Job Satisfaction in Nigeria and South Africa}

\author{
Sunday Itasanmi ${ }^{1}$, Morakinyo Akintolu ${ }^{2}, \&$ Mathew T. Oni ${ }^{3}$ \\ ${ }^{1}$ Dept of Adult Education, University of Ibadan, Nigeria. \\ ${ }^{2}$ UNESCO Chair on Open Distance Learning, Dept of Educational Foundations, \\ University of South Africa. \\ ${ }^{3}$ Dept of Early Childhood and Educational Foundations, University of Ibadan, Nigeria.
}

\begin{abstract}
This study reported a survey conducted to assess the job satisfaction level among adult literacy facilitators in Nigeria and South Africa. The study adopted a quantitative approach and data was collected from eighty-six (86) adult literacy facilitators (Nigeria-50 and South Africa-36) randomly selected from Oyo State, Nigeria and King Cetshwayo District, KwaZulu-Natal province, South Africa. A structured questionnaire validated by experts and pilot-tested among primary School teachers serves as the research instrument. Data collected from the study were analysed using frequency count, simple percentages, mean, multiple regression analysis and T-test. Results revealed that adult literacy facilitators' job satisfaction level in the two countries is on average. Provision of a positive working environment in terms of improvement in the infrastructural facilities in the literacy centre was ranked first amongst others as ways to improve the job satisfaction of literacy facilitators. There was, however, no statistical difference in job satisfaction among literacy facilitators in Nigeria and South Africa. Therefore, it was concluded that conscious effort must be made at mapping out strategies to improve literacy facilitators' job satisfaction to enhance adult literacy delivery in the two countries.
\end{abstract}

Keywords: Adult literacy, Facilitator, Job satisfaction, Nigeria, South Africa, Oyo state, KwaZulu-Natal province

\section{Introduction}

Work is an essential part of an individual's life as it takes a substantial part of the productive time of the individual with a hopeful desire to either fulfil personal desires or family needs. Satisfaction, on the other hand, refers to how an individual feels after a need is satisfied. Job 
satisfaction is defined as the level to which a worker has a sense of job stability, career growth and a comfortable work-life balance. Thus, it describes the favourableness or otherwise with which an employee views their jobs, and this often occurs when job requirements are suited to the wants and expectations of the workers (Misha, 2013). UKEssays (2018, para. 1), defines job satisfaction as the emotional response of a worker to different job-related factors occasioned by "finding pleasure, comfort, confidence, rewards, personal growth, and various positive opportunities, including upward mobility, recognition and appraisal did on merit with monetary value as compensation". In other words, workers' job satisfaction describes an attitudinal element of workers towards their job and this is dependent on the perception of the degree to which they like or dislike the job (Akinwale and George, 2020). Job satisfaction is perceived to be directly linked to workers' productivity and general well-being. Therefore, it implies "doing a job one enjoys, doing it well and being rewarded for one's efforts" (Aziri, 2011, pp. 2). Job satisfaction literature is dominated by two theories, namely, two-factor theory, and expectancy theory. The two-factor theory propounded by Herzberg, Mausner and Snyderman (1959) posit, on one hand, that job satisfaction is prompted by the existence of motivating factors (elements of the work) and job dissatisfaction is a result of the absence of hygiene factors (elements of the context of work). The expectancy theory proposed by Vroom (1964), on the other hand, hypothesizes that workers' evaluation of job satisfaction is dependent on the inconsistency between expectation from the work and what is received. Thus, the extent to which expectations matches with real achievement is what is called job satisfaction (Miao, Komil ugli Fayzullaey and Dedahanov, 2020).

Job satisfaction of workers is influenced by many factors such as the nature of work, salary, career advancement opportunities, work conditions, organization management and workgroups (Pervin and Kabir, 2011; Aziri, 2011). According to Glisson and Durick (1988, cited in Miao, et al., 2020), three factors predict the job satisfaction of workers. The first factor is related to the nature of the job tasks carried out by the workers, and the second factor is related to the nature of the organization in which work is done, while the third factor is centred on the nature of the individual that performs the task. Other determinants of job satisfaction include quality and quantity of work, satisfaction with payment, technology, individual differences, nature and style of supervision, recognition and benefits, prior expectations, promotional opportunity and fairness, leadership, social interaction (Miao, et al., 2020). Whatever way job satisfaction and its determinants are conceived, its importance to workers' productivity and the general development of an organization cannot be overemphasized. It is 
the main factor when it comes to the efficiency and effectiveness of an organization. Studies have shown that job satisfaction is significantly linked to employee productivity, loyalty, or absenteeism. A worker, who receives rewards considered equitable and commensurate may likely feel satisfied and motivated to perform better. Generally, a satisfied employee is very likely to be creative and innovative in the discharge of his or her duties. According to Sharma and Jyoti (2009), the more satisfied an employee is, the more the propensity to come up with breakthroughs that allow the organization to grow and change positively with time and adapt to the ever-growing yearnings of its stakeholders.

Education is the basic building block of every society. It is the single best investment countries can make to build prosperous, healthy, and equitable societies. It is a basic human right and a necessary condition for the sustainable social and economic development of any nation (UNESCO, 1994). Literacy is a component of basic education and a foundation for lifelong learning. The importance of literacy acquisition to individuals, communities and societies cannot be overemphasized. Access to literacy education serves as a springboard not only for enhancing human capabilities to eradicate poverty but also to "facilitate the achievement of environmental and ethical awareness, values, and skills consistent with sustainable development and effective participation in decision-making" (United Nations., 2007; Institute for Statistics (UIS), 2010). Countries and international and multilateral agencies have made concerted efforts at achieving literacy education for all. However, the world is still home to 773 million illiterate adults, the majority of whom are women and 258 million out of school children and youth (UNESCO., 2019; UNESCO., 2020). Large inequalities exist globally in literacy achievement notably between sub-Saharan Africa and the rest of the world (Roser and Ortiz-Ospina, 2018). Sub-Saharan Africa has one of the lowest adult literacy rates in the world with a literacy rate of $61 \%$ and the number of the illiterate population continues to grow. Fourteen (14) of the twenty-two (22) countries with literacy rates below $60 \%$ in the world are in Sub-Saharan Africa (UNESCO, 2007).

All nations seek ways of improving the educational attainment of their citizens and how to make their students and learners achieve high academic outcomes. This is no less so in subSahara African countries. Researchers, educators, and policymakers are all in search of factors and strategies that can produce or enhance a better educational system. Central to a successful educational system is the quality and quantity of the teachers (literacy facilitators inclusive) and attracting and retaining these teachers. Understanding the factors essential to teachers' job 
satisfaction for optimal performance must therefore be understood as multidimensional. It is equally critical for ensuring teachers' performance and commitment and for the general effectiveness of the educational system (Sharma and Jyoti, 2009). Oxenham (2004), noted that the quality and effectiveness of any adult literacy programme depends on the facilitators who teach or interact with the intended beneficiaries of the programme. Job satisfaction for the literacy facilitators implies the capacity of their work to meet their personal needs even as they improve their job performance (Ololube, 2006).

Adult literacy facilitators come from diverse backgrounds and while some are engaged in literacy teaching as full or part-time literacy professionals, very many are volunteer workers with varying levels of education and experience. According to Warkineh, Rogers and Danki (2017), literacy facilitators in developing nations include full-time school teachers and employees of governments or non-governmental organizations (NGOs) who teach adults outside their main working hours or are required to teach adults as part of their professional duties. In some countries, contract staff are engaged to teach adults, however, most of the facilitators teaching in literacy centres are local people with no formal teaching qualifications and are engaged either as part-time or on a casual basis. Although most are rewarded, it is often pittance and irregular (Warkineh, et al. 2017). Muthii (2012) therefore concludes that the general working condition of most literacy facilitators needs attention as they lack good conditions of service, including a good career prospect. McCaffery, Merrifield and Millican (2007) observe that literacy facilitators remain one of the least supported groups of educators globally as they receive little or no regular remuneration for their job, lack job security, and they seldom enjoy training opportunities and ongoing professional support. This often affects their discharge of responsibility to the teeming adult learners who require their expertise to guide their learning process (McCaffery, et al., 2007; Muthii, 2012; Oyelami and Alokan, 2019).

Poor work conditions for adult literacy facilitators continue to diminish their performance which in turn has a devastating impact on literacy promotional efforts, especially in developing countries where the adult illiteracy rate is very high (UIS, 2010; Oyelami and Alokan, 2019). Limited educational opportunities for illiterate adults negatively affect the prospects of sustainable development since illiterates lack the capacity of contributing meaningfully to the development of the nation at large. Unless a drastic measure is taken to understand the state of job satisfaction of literacy facilitators and its determinants, all efforts at raising the bar of adult literacy provision especially in Sub-Saharan Africa will remain 
inconsequential. Hence, the critical role that adult literacy could play in reversing the trend and consequent need to seriously engage with and understand the job satisfaction needs of these teachers in Africa. This study, therefore, investigates the job satisfaction level and its determinants among literacy facilitators in Nigeria and South Africa, the two leading countries in Sub-Saharan Africa. It seeks to contribute to the sparse empirical studies on the job satisfaction of literacy facilitators in these two countries.

\subsection{Research Questions}

The following research questions guide the conduct of the study:

1. What is the job satisfaction level among adult literacy facilitators in Nigeria and South Africa?

2. What are the possible ways of improving the job satisfaction level of adult literacy facilitators in the two countries?

3. What is the joint contribution of age, gender, qualification, year of services, nature of service, marital status, and ownership of literacy centre to job satisfaction of literacy facilitators?

4. What is the relative contribution of age, gender, qualification, year of services, nature of service, marital status, and ownership of literacy centre on job satisfaction of literacy facilitators?

5. What is the difference in job satisfaction between literacy facilitators in Nigeria and South Africa?

\section{Adult Literacy Provision in Nigeria and South Africa}

\subsection{The Nigerian Situation}

Adult literacy provision in colonial Nigeria was dominated by Christian missionaries whose principal intention was to promote religious literacy. While the northern part of the country was served by Quranic schools and Islamic clerics serving as facilitators who exposed learners to Arabic literacy, the southern part of the country had the Christian missionaries who exposed the people to Western education. The British colonial governments eventually took over from the missionaries when the Colonial Officer recommended a national literacy campaign in its memorandum on Education Policy in British Tropical Africa in 1946. Between 1952 and 1960 independence of Nigeria, the regional governments initiated policies aimed at developing their education sectors in their domains. For instance, the Western and Eastern regional governments 
initiated Universal Primary Education (UPE), and the Northern regional government opted for free primary and adult literacy as a strategy in their war against ignorance (Yusuf, Ladan, Idris and Halilu, 2013).

The above efforts constituted the bedrock for adult literacy development in the country after independence. An Adult literacy institute was established in Ibadan in 1963 by UNESCO for manpower development of adult educators, an event that gave a significant impetus to literacy promotional effort in the country. In 1982, the federal government launched a 10 -year national mass literacy campaign followed by a directive that all states in the country should establish an agency for mass education. In 1990, the National Commission for Mass Literacy and Non-formal Education (NMEC)was established in the country. This was followed in 1991 by the establishment of the National Mass Education Commission and in 2000, Universal Basic Education was established, which Act opened literacy opportunities for all (Yusuf, Ladan, Idris and Halilu, 2013; Chieke, Madu, and Ewelum, 2017).

Presently, adult literacy provision in each Nigerian state is coordinated by an Adult and Non-Formal Agency established by the states. For example, in Oyo State, Agency for Adult and Non-Formal Education (Oyo AANFE) was established in 1987 and took off in 1988. Its core vision was eradicating illiteracy among the citizenry of the state and providing continuing education opportunities for early school leavers as well as economic empowerment through exposure to skills acquisition. The agency collaborates with relevant NGOs and donor agencies to implement programmes that bear on literacy promotion and life-skills development for the people. The two major categories of literacy programmes providers in the state are the NGOs/Faith-based literacy centres, on the other hand, and government literacy centres, on the other. The state's Agency coordinates all academic activities in all the literacy programmes for Adult and Non-Formal Education (Oyo State Agency for Adult and Non-formal Education. n.d.).

\subsection{The South African Situation}

Adult literacy education in South Africa dates to the late seventeenth century, but it became significant in the twentieth. Before the beginning of the $20^{\text {th }}$ century, adult literacy provision in South Africa was limited being an offshoot of missionary provision of Western education to the people. Until the overthrow of the Apartheid in South Africa, its government discouraged and discriminated against the majority black population, creating obstacles to their education. Bantu Education Act promulgated in 1953 was the foundation of the apartheid education 
system in South Africa. The act handed the education control frameworks to the state. Thus, educational provision to black people became an imprisonable offence unless it is in a government registered school (Aitchison, 2003). This produced an astronomical increase in the population of functional illiterates in the country. To curb the high and growing rate of illiteracy, some religious, political, and Non-governmental organizations such as Christian churches, the Bureau of Literacy and Literature and 'Operation Upgrade' established night schools and literacy classes in many parts of the country, much of which efforts were frustrated by government insistence on the exclusion of black people from acquiring education and training so that they would remain at the lower rungs of the economy as a cheap source of labour (Aitchison, 2003; Addae, 2016). This was the hallmark of the apartheid regime (Ocampo, 2004). In 1994, the apartheid regime ended and the National Unity government opened educational opportunities to all to meet the critical need for rapid socio-economic development of the country. The new regime enacted and began the implementation of a policy for equitable access to education for all irrespective of sex, gender, and race. In 1995, the Department of Education established the Directorate for Adult Basic to coordinate adult basic education activities as part of the government's show of commitment to the provision of adult literacy to the people. The massive and coordinated efforts of the Department of Education led to the establishment of adult literacy centres across all provinces of the country. Adult Basic Education and training in South Africa is organized under six different learning areas drawn from twelve learning subjects. These include language, literacy and communication, mathematical literacy, mathematics and mathematical sciences, human and social sciences, natural sciences, technology and economic management sciences. Some of the subjects that adult learners can choose from are languages, mathematics, numeracy, business economics, biology, accountancy, geography, and history. To add value to the certificates awarded to adult learners, the South African Qualifications Authority (SAQA) made various levels of Adult Basic Education and Training (ABET) equivalent to those of the formal school system.

\subsection{Comparison of Adult Literacy Education between Nigeria and South Africa}

The goal of adult education in the two countries was to empower people with survival skills of reading, writing and arithmetic and to provide functional literacy skills through remedial education, further education, and vocational training. The history of adult education in Nigeria and South Africa are similar. It evolved from missionary activities. After independence, the coordination of adult and basic education was centrally controlled with autonomy granted to 
sub-national governments or states to organize and administer adult education to local people. However, while access to literacy education is constitutionally guaranteed in South Africa, it is restricted to primary schooling in Nigeria and it is not constitutionally guaranteed. Because of the Bantu Act in South Africa that deprived people of access to education during apartheid government, adult education is consciously promoted to bring in those that have been deprived of educational access but nothing is being done by the Nigerian government in this regard (Zulu, n.d.). Though Nigeria gained Independence before South Africa, it is estimated that Nigeria has over forty-one million illiterates (literacy rate- 62\%), compared to five million illiterates (literacy rate- 87\%) in South Africa (UNESCO Institute of Statistics. a \& b, 2017). A cursory look at ABET (https://www.abet.co.za/) and NMEC (https://www.nmec.gov.ng/) websites, indicates that adult basic education is more coordinated in South Africa compared to Nigeria. For instance, the ABET website gave a clear philosophy of the agency as regards adult and basic education in South Africa, provided detailed information on available literacy centres to learners, various examinations, government roles etc., while the NMEC website only showcases general information for the public consumption. This could be taken as a reflection of the respective value placed on adult literacy promotion in each of the countries.

\section{Methodology}

A survey research design was adopted for this study. The general population of the study consisted of adult literacy facilitators in Nigeria and South Africa but the study targeted adult literacy facilitators in Oyo State, Nigeria and King Cetshwayo District, KwaZulu-Natal province, South Africa. Eighty-six (86) participants were randomly selected (Nigeria 50 and South Africa-36). A structured questionnaire titled "Adult Literacy Facilitators' Job Satisfaction Questionnaire" was validated by experts and pilot-tested among primary School teachers. A Cronbach's Alpha coefficient of 7.0 was obtained for the questionnaire. The questionnaire focuses on three domains: demographic, job satisfaction, and the improvement of adult literacy facilitators' job satisfaction. Data collected from the study were analysed using descriptive statistics of frequency count, simple percentages, mean and inferential statistics of multiple regression analysis and Independent Sample T-test. To answer research 1, the average mean was calculated based on the respondents' scores against each job satisfaction item multiplied by the scores under each Likert scale point. The decision on adult literacy facilitators' job satisfaction level was determined using the following criteria; average mean $\leq$ $2=$ Low; average mean $>2 \leq 3=$ average; and average mean $>3=$ high. For research question 2 , the mean score of items in 'ways of improving adult literacy facilitators' job satisfaction' were 
ranked according to the mean value of each item. Research questions 4 and five were answered using multiple regression analysis while T-Test was used to answer research question 5 .

\subsection{Limitation of the study}

Because the target populations derived from a state and province in Nigeria and South Africa respectively, the study sample is not nationally representative of the general population of both countries; hence, the results of the study should be interpreted cautiously in this light.

\section{4. $\quad$ Results}

RQ1: What is the job satisfaction level among adult literacy facilitators in Nigeria and South Africa?

Table 1: Job Satisfaction among adult literacy facilitators in Nigeria and South Africa

\begin{tabular}{|c|c|c|c|c|c|c|}
\hline $\mathbf{S} / \mathbf{N}$ & Item Description & $\begin{array}{l}\text { SA } \\
(\%)\end{array}$ & $\begin{array}{c}\mathbf{A} \\
(\%)\end{array}$ & $\begin{array}{c}\text { D } \\
(\%)\end{array}$ & $\begin{array}{l}\text { SD } \\
(\%)\end{array}$ & $\overline{\mathrm{X}}$ \\
\hline 1 & $\begin{array}{l}\text { My job as an adult literacy facilitator is } \\
\text { compatible with my experience }\end{array}$ & $\begin{array}{c}22 \\
(25.6)\end{array}$ & $\begin{array}{c}53 \\
(61.6)\end{array}$ & $\begin{array}{c}8 \\
(9.3)\end{array}$ & $\begin{array}{c}3 \\
(3.5)\end{array}$ & 3.09 \\
\hline 2 & $\begin{array}{l}\text { The literacy organiser provides the } \\
\text { opportunity for professional growth }\end{array}$ & $\begin{array}{c}20 \\
(23.3)\end{array}$ & $\begin{array}{c}53 \\
(61.6)\end{array}$ & $\begin{array}{c}3 \\
(3.5)\end{array}$ & $\begin{array}{c}10 \\
(11.6)\end{array}$ & 2.97 \\
\hline 3 & $\begin{array}{l}\text { The job provides good opportunities for } \\
\text { promotion }\end{array}$ & $\begin{array}{c}14 \\
(16.3)\end{array}$ & $\begin{array}{c}43 \\
(50.0)\end{array}$ & $\begin{array}{c}17 \\
(19.8)\end{array}$ & $\begin{array}{c}12 \\
(14.0)\end{array}$ & 2.69 \\
\hline 4 & $\begin{array}{l}\text { I have freedom of decision to perform my } \\
\text { task as a facilitator }\end{array}$ & $\begin{array}{c}18 \\
(20.9)\end{array}$ & $\begin{array}{c}56 \\
(65.1)\end{array}$ & $\begin{array}{c}8 \\
(9.3)\end{array}$ & $\begin{array}{c}4 \\
(4.7)\end{array}$ & 3.02 \\
\hline 5 & $\begin{array}{l}\text { My job position and responsibilities are } \\
\text { clearly defined }\end{array}$ & $\begin{array}{c}11 \\
(12.8)\end{array}$ & $\begin{array}{c}57 \\
(66.3)\end{array}$ & $\begin{array}{c}14 \\
(16.3)\end{array}$ & $\begin{array}{c}4 \\
(4.7)\end{array}$ & 2.87 \\
\hline 6 & $\begin{array}{l}\text { I have sufficient professional authority and } \\
\text { autonomy at work }\end{array}$ & $\begin{array}{c}8 \\
(9.3)\end{array}$ & $\begin{array}{c}47 \\
(54.7)\end{array}$ & $\begin{array}{c}25 \\
(29.1)\end{array}$ & $\begin{array}{c}6 \\
(7.0)\end{array}$ & 2.66 \\
\hline 7 & My work as a facilitator is not stressful & $\begin{array}{c}5 \\
(5.8)\end{array}$ & $\begin{array}{c}40 \\
(46.5)\end{array}$ & $\begin{array}{c}30 \\
34.9)\end{array}$ & $\begin{array}{c}11 \\
(12.8)\end{array}$ & 2.45 \\
\hline 8 & $\begin{array}{l}\text { I get the necessary information to perform } \\
\text { my job as a literacy facilitator }\end{array}$ & $\begin{array}{c}13 \\
(15.1)\end{array}$ & $\begin{array}{c}54 \\
(62.8)\end{array}$ & $\begin{array}{c}16 \\
(18.6)\end{array}$ & $\begin{array}{c}3 \\
(3.5)\end{array}$ & 2.90 \\
\hline 9 & $\begin{array}{l}\text { My salary as a literacy facilitator is fair } \\
\text { and sufficient }\end{array}$ & $\begin{array}{c}1 \\
(1.2)\end{array}$ & $\begin{array}{c}18 \\
(20.9)\end{array}$ & $\begin{array}{c}38 \\
(44.2)\end{array}$ & $\begin{array}{c}29 \\
(33.7)\end{array}$ & 1.90 \\
\hline
\end{tabular}




\begin{tabular}{|c|c|c|c|c|c|c|}
\hline 10 & $\begin{array}{l}\text { My salary is higher than my peers in other } \\
\text { literacy centres }\end{array}$ & $\begin{array}{c}5 \\
(5.8)\end{array}$ & $\begin{array}{c}11 \\
(12.8)\end{array}$ & $\begin{array}{c}34 \\
(39.5)\end{array}$ & $\begin{array}{c}36 \\
(41.9)\end{array}$ & 1.83 \\
\hline 11 & $\begin{array}{l}\text { The literacy centre has a clear policy } \\
\text { regarding salaries and allowances }\end{array}$ & $\begin{array}{c}4 \\
(4.7)\end{array}$ & $\begin{array}{c}17 \\
(19.8)\end{array}$ & $\begin{array}{c}36 \\
(41.9)\end{array}$ & $\begin{array}{c}29 \\
(33.7)\end{array}$ & 1.95 \\
\hline 12 & $\begin{array}{l}\text { The number of facilitators available is } \\
\text { sufficient to run the literacy centre without } \\
\text { overloading me }\end{array}$ & $\begin{array}{c}10 \\
(11.6)\end{array}$ & $\begin{array}{c}30 \\
(34.9)\end{array}$ & $\begin{array}{c}27 \\
(31.4)\end{array}$ & $\begin{array}{c}19 \\
(22.1)\end{array}$ & 2.36 \\
\hline 13 & $\begin{array}{l}\text { The classroom amenities (chair, } \\
\text { environment, toilet etc) are available, } \\
\text { comfortable and safe }\end{array}$ & $\begin{array}{c}8 \\
(9.3)\end{array}$ & $\begin{array}{c}36 \\
(41.9)\end{array}$ & $\begin{array}{c}26 \\
(30.2)\end{array}$ & $\begin{array}{c}16 \\
(18.6)\end{array}$ & 2.42 \\
\hline 14 & $\begin{array}{l}\text { There is no shortfall in the financial } \\
\text { resources of the centre }\end{array}$ & $\begin{array}{c}3 \\
(3.5)\end{array}$ & $\begin{array}{c}22 \\
(25.6)\end{array}$ & $\begin{array}{c}33 \\
(38.4)\end{array}$ & $\begin{array}{c}28 \\
(32.6)\end{array}$ & 2.00 \\
\hline 15 & $\begin{array}{l}\text { There is a collegiality and team spirit with } \\
\text { colleagues }\end{array}$ & $\begin{array}{c}24 \\
(27.9)\end{array}$ & $\begin{array}{c}50 \\
(58.1)\end{array}$ & $\begin{array}{c}9 \\
(10.5)\end{array}$ & $\begin{array}{c}3 \\
(3.5)\end{array}$ & 3.10 \\
\hline 16 & $\begin{array}{l}\text { Work relations are satisfactory in the } \\
\text { literacy centre }\end{array}$ & $\begin{array}{c}21 \\
(24.4)\end{array}$ & $\begin{array}{c}54 \\
(62.8)\end{array}$ & $\begin{array}{c}9 \\
(10.5)\end{array}$ & $\begin{array}{c}2 \\
(2.3)\end{array}$ & 3.09 \\
\hline 17 & $\begin{array}{l}\text { There is good interpersonal } \\
\text { communication and cooperation among } \\
\text { stakeholders in the literacy centre }\end{array}$ & $\begin{array}{c}14 \\
(16.3)\end{array}$ & $\begin{array}{c}53 \\
(61.6)\end{array}$ & $\begin{array}{c}16 \\
(18.6)\end{array}$ & $\begin{array}{c}3 \\
(3.5)\end{array}$ & 2.91 \\
\hline 18 & $\begin{array}{l}\text { Activities in the centre are coordinated and } \\
\text { integrated }\end{array}$ & $\begin{array}{c}13 \\
(15.1)\end{array}$ & $\begin{array}{c}51 \\
(59.3)\end{array}$ & $\begin{array}{c}21 \\
(24.4)\end{array}$ & $\begin{array}{c}1 \\
(1.2)\end{array}$ & 2.88 \\
\hline 19 & $\begin{array}{l}\text { There is an opportunity for socialising with } \\
\text { colleagues }\end{array}$ & $\begin{array}{c}17 \\
(19.8)\end{array}$ & $\begin{array}{c}44 \\
(51.2)\end{array}$ & $\begin{array}{c}23 \\
(26.7)\end{array}$ & $\begin{array}{c}2 \\
(2.3)\end{array}$ & 2.88 \\
\hline 20 & $\begin{array}{l}\text { My immediate supervisor treats facilitators } \\
\text { fairly }\end{array}$ & $\begin{array}{c}16 \\
(18.6)\end{array}$ & $\begin{array}{c}60 \\
(69.8)\end{array}$ & $\begin{array}{c}6 \\
(7.0)\end{array}$ & $\begin{array}{c}4 \\
(4.7)\end{array}$ & 3.02 \\
\hline 21 & $\begin{array}{l}\text { My immediate supervisor uses positive } \\
\text { feedback with facilitators }\end{array}$ & $\begin{array}{c}18 \\
(20.9)\end{array}$ & $\begin{array}{c}56 \\
(65.1)\end{array}$ & $\begin{array}{c}10 \\
(11.6)\end{array}$ & $\begin{array}{c}2 \\
(2.3)\end{array}$ & 3.05 \\
\hline
\end{tabular}

Table 1 presents results on the level of job satisfaction among adult literacy facilitators in Nigeria and South Africa. The results revealed that adult literacy facilitators' job satisfaction levels in the two countries are on average (average mean $=2.66$ ). Results showed that based on the mean scores of their responses, facilitators in the two countries have a high level of satisfaction in terms of collegiality and team spirit with colleagues (Mean=3.10), job 
compatibility with experience (Mean=3.09), work relations (Mean=3.09), feedbacks from supervisor (Mean=3.02), and treatments from their supervisor $(M e a n=3.05)$ as well as the freedom of decision to perform as facilitators (Mean=3.02). Also, the table revealed that adult literacy facilitators have an average level of satisfaction with opportunity for professional growth (Mean=2.97), interpersonal communication and cooperation among all stakeholders (Mean=2.91), getting the necessary information to perform their job (Mean=2.90), coordination and integration of activities in the centre (Mean=2.88), the opportunity for socialization (Mean=2.88). Equally, they have an average level of satisfaction with clearly defined job positions and responsibilities (Mean=2.87), opportunities for promotion (Mean=2.69), a sense of professional authority and autonomy at work (Mean=2.66), stress-free nature of their work (Mean=2.45), available infrastructure (Mean=2.42), and the sufficiency of facilitators to run the literacy centre (Mean=2.36). However, adult literacy facilitators in the two countries have a low-level satisfaction with financial resources availablity to the centre (Mean=2.00), with the policies regarding salaries and allowances (Mean=1.95), fairness in salary for facilitators (Mean=1.90), comparison of facilitators' salary with their peers in other literacy centres $($ Mean=1.83).

RQ2: What are the possible ways of improving the job satisfaction level of adult literacy facilitators?

Table 2: ways of improving adult literacy facilitators' job satisfaction

\begin{tabular}{|l|l|l|l|l|l|l|l|}
\hline S/N & Items & $\begin{array}{c}\text { SA } \\
(\%)\end{array}$ & $\begin{array}{c}\text { A } \\
(\%)\end{array}$ & $\begin{array}{c}\text { D } \\
(\%)\end{array}$ & $\begin{array}{l}\text { SD } \\
(\%)\end{array}$ & $\bar{X}$ & Rank \\
\hline 1 & $\begin{array}{l}\text { Providing a positive working environment, } \\
\text { i.e. Improvement in the infrastructural } \\
\text { facilities in place in the literacy centre }\end{array}$ & $\begin{array}{l}32 \\
(37.2)\end{array}$ & $\begin{array}{l}40 \\
(46.5)\end{array}$ & $\begin{array}{l}10 \\
(11.6)\end{array}$ & $\begin{array}{l}4 \\
(4.7)\end{array}$ & 3.16 & $1^{\text {st }}$ \\
\hline 2 & $\begin{array}{l}\text { Giving due reward and recognition to adult } \\
\text { literacy facilitators }\end{array}$ & $\begin{array}{l}26 \\
(30.2)\end{array}$ & $\begin{array}{l}43 \\
(50.0)\end{array}$ & $\begin{array}{l}13 \\
(15.1)\end{array}$ & $\begin{array}{l}4 \\
(4.7)\end{array}$ & 3.06 & $4^{\text {th }}$ \\
\hline 3 & $\begin{array}{l}\text { Regular review and prompt payment of } \\
\text { compensation }\end{array}$ & $\begin{array}{l}28 \\
(32.6)\end{array}$ & $\begin{array}{l}36 \\
(41.9)\end{array}$ & $\begin{array}{l}17 \\
(19.8)\end{array}$ & $\begin{array}{l}5 \\
(5.8)\end{array}$ & 3.01 & $6^{\text {th }}$ \\
\hline 4 & $\begin{array}{l}\text { Improvement in the general welfare of } \\
\text { literacy facilitators }\end{array}$ & $\begin{array}{l}46 \\
(30.2)\end{array}$ & $\begin{array}{l}452.3) \\
(12.8)\end{array}$ & $\begin{array}{l}4 \\
(4.7)\end{array}$ & 3.08 & $3^{\text {rd }}$ \\
\hline 5 & $\begin{array}{l}\text { Allowing facilitators to contribute their } \\
\text { ideas in content planning and general } \\
\text { management of the literacy centre }\end{array}$ & $\begin{array}{l}31 \\
(36.0)\end{array}$ & $\begin{array}{l}50.0) \\
(5.8)\end{array}$ & $\begin{array}{l}7 \\
(8.1)\end{array}$ & 3.14 & $2^{\text {nd }}$ \\
\hline 6 & $\begin{array}{l}\text { Provision for professional training and } \\
\text { career advancement }\end{array}$ & $\begin{array}{l}28 \\
(32.6)\end{array}$ & $(45.3)$ & $\begin{array}{l}12 \\
(14.0)\end{array}$ & $\begin{array}{l}7 \\
(8.1)\end{array}$ & 3.02 & $5^{\text {th }}$ \\
\hline
\end{tabular}




\begin{tabular}{|l|l|l|l|l|l|l|l|}
\hline 7 & Provision for good performance bonuses & $\begin{array}{l}24 \\
(27.9)\end{array}$ & $\begin{array}{l}40 \\
(46.5)\end{array}$ & $\begin{array}{l}12 \\
(14.0)\end{array}$ & $\begin{array}{l}10 \\
(11.6)\end{array}$ & 2.91 & $9^{\text {th }}$ \\
\hline 8 & $\begin{array}{l}\text { Supportive evaluation and supervision of } \\
\text { literacy facilitators }\end{array}$ & $\begin{array}{l}53 \\
(22.1)\end{array}$ & $\begin{array}{l}6 \\
(61.6)\end{array}$ & $\begin{array}{l}8 \\
(7.0) \\
(9.3)\end{array}$ & 2.97 & $8^{\text {th }}$ \\
\hline 9 & $\begin{array}{l}\text { Promotion of literacy facilitators as at } \\
\text { when due }\end{array}$ & $\begin{array}{l}23 \\
(26.7)\end{array}$ & $\begin{array}{l}(53.5) \\
(11.6)\end{array}$ & $\begin{array}{l}7 \\
(8.1)\end{array}$ & 2.99 & $7^{\text {th }}$ \\
\hline 10 & $\begin{array}{l}\text { Promotion of good interpersonal relations } \\
\text { among all stakeholders in the literacy } \\
\text { centre }\end{array}$ & $\begin{array}{l}27 \\
(31.4)\end{array}$ & $\begin{array}{l}49 \\
(57.0)\end{array}$ & $(5.8)$ & $\begin{array}{l}5 \\
(5.8)\end{array}$ & 3.14 & $2^{\text {nd }}$ \\
\hline
\end{tabular}

Table 2 shows results on ways of improving adult literacy facilitators' job satisfaction. Provision of a positive working environment in terms of improvement in the infrastructural facilities in the literacy centre was ranked first based on the mean score of their responses followed by facilitators' contribution to content planning. General management of the literacy centre and promotion of good interpersonal relations among all stakeholders in the literacy centre was jointly ranked $2^{\text {nd }}$ as the best ways to improve job satisfaction of literacy facilitators. Improvement in the general welfare of literacy facilitators, giving due reward and recognition to adult literacy facilitators, making provision for professional training and career advancement, and regular review and prompt payment of compensation were ranked $3^{\text {rd }}, 4^{\text {th }}$, $5^{\text {th }}$ and $6^{\text {th }}$ respectively. Also, promotion of literacy facilitators as at when due, supportive evaluation and supervision of literacy facilitators and provision for good performance bonuses were ranked $7^{\text {th }}, 8^{\text {th }}$ and $9^{\text {th }}$ respectively as ways to improve facilitators' job satisfaction.

RQ3: What is the joint contribution of age, gender, qualification, year of services, nature of service, marital status and centre ownership on Job Satisfaction of literacy facilitators?

Table 3: Summary of multiple regression on the joint prediction of age, gender, qualification, year of services, nature of service, marital status, and ownership of literacy centre on Job Satisfaction of literacy facilitators

$\mathrm{R}=.526$

$\mathrm{R}^{2}=.770$

Adj. $R^{2}=.963$

Std. Error $=8.66305$

\begin{tabular}{|l|l|c|c|c|c|c|}
\hline Model & $\begin{array}{l}\text { Sum of } \\
\text { Squares }\end{array}$ & Df & Mean Square & F & $\begin{array}{l}\text { Sig. }(p- \\
\text { value })\end{array}$ & Remark \\
\hline Regression & 805.198 & 7 & 115.028 & & & \\
Residual & 2101.358 & 28 & 75.049 & 21.533 & .020 & Sig. \\
Total & 2906.556 & 35 & & & & \\
\hline
\end{tabular}

As indicated in table 3, it was revealed that the linear combination of the joint prediction of age, gender, qualification, year of services, nature of service, marital status and ownership of 
literacy centre and job satisfaction of adult literacy facilitators $(\mathrm{F}(7 / 28)=21.533, p<0.05)$. The result yielded a coefficient of multiple regression of $\mathrm{R}=0.526$ and multiple $\mathrm{R}$-square of 0.770. The result also revealed that Adjusted $\mathrm{R}^{2}=0.963$; indicating that about $96.3 \%$ of the variance was accounted for by the independent variables. This implied that there is a joint prediction of age, gender, qualification, year of services, nature of service, and marital status and ownership of literacy centre on adult literacy facilitators' job satisfaction.

Q4: What is the relative contribution of age, gender, qualification, year of services, nature of service, marital status, and ownership type of literacy centre on job satisfaction of literacy facilitators?

Table 4: Summary of multiple regression on the relative contribution of age, gender, qualification, year of services, nature of service, marital status, and ownership of literacy centre on job satisfaction of literacy facilitators

\begin{tabular}{|c|c|c|c|c|c|c|}
\hline \multirow[t]{2}{*}{ Variable } & \multicolumn{2}{|c|}{$\begin{array}{c}\text { Unstandardised } \\
\text { coefficients }\end{array}$} & \multirow{2}{*}{$\begin{array}{c}\text { Standardised } \\
\text { coefficients } \\
\text { Beta }(\beta)\end{array}$} & \multirow[b]{2}{*}{$\mathrm{t}$} & \multirow{2}{*}{$\begin{array}{c}\text { Sig. } \\
(p \text {-value })\end{array}$} & \multirow[b]{2}{*}{ Remark } \\
\hline & B & Std. Error & & & & \\
\hline (Constant) & 33.835 & 12.801 & - & 2.643 & .013 & \\
\hline Age & 1.528 & 2.018 & .179 & 10.757 & .046 & Sig. \\
\hline Sex & 2.951 & 5.431 & .091 & .545 & .590 & Not Sig. \\
\hline Academic Qualification & 4.065 & 2.210 & .334 & 11.840 & .008 & Sig. \\
\hline Years of Service & 0.521 & 1.513 & .073 & .344 & .733 & Not Sig. \\
\hline Nature of Service & 2.300 & 4.508 & .089 & .510 & .614 & Not Sig. \\
\hline Marital status & .581 & 2.457 & .049 & .236 & .815 & Not Sig. \\
\hline Ownership type & 2.866 & 2.361 & .200 & 11.214 & .023 & Sig. \\
\hline
\end{tabular}

Table 4.10 shows the unstandardised regression weight ( $($ ), the standardized error of estimate (SEß), the standardised coefficient, the t-ratio and the level at which the t-ratio is significant. As indicated in the table, academic qualification $(\beta=0.334, \mathrm{t}=11.840, p<0.05)$ was tested significant on the job satisfaction among adults literacy facilitators followed by ownership $(\beta=.200, \mathrm{t}=11.214, p<0.05)$ and age $(\beta=.179, \mathrm{t}=10.757, p<0.05)$ have relative contribution while sex $(\beta=.091, t=.545, p>0.05)$, years of service, $(\beta=.073, t=.344, p>0.05)$, nature of 
service $(\beta=.089, \mathrm{t}=.510, p>0.05)$ and marital status $(\beta=.049, \mathrm{t}=.236, p>0.05)$ have no relative contribution to job satisfaction among adults literacy facilitators. This implies that academic qualification, ownership type of literacy centre and age contribute to the relative job satisfaction of facilitators. In contrast, sex, year of services, nature of service and marital status have no relative contribution.

RQ5: What is the difference in job satisfaction between literacy facilitators in Nigeria and South Africa?

Table 5 showing T-test of difference in literacy facilitators' job satisfaction in Nigeria and South Africa

\begin{tabular}{|l|l|l|l|l|l|l|l|l|}
\hline Variable & Location & N & Mean & SD & df. & t-Cal & t-Crit & P \\
\hline \multirow{2}{*}{$\begin{array}{l}\text { Job } \\
\text { Satisfaction }\end{array}$} & South African & 36 & 59.50 & 9.464 & & & & \\
\cline { 2 - 5 } & Nigeria & 50 & 58.76 & 6.409 & 84 & .432 & 1.960 & $0.667(\mathrm{p}<0.05)$ \\
\cline { 2 - 5 } & Total & 86 & & & & & & Not Significant \\
\hline
\end{tabular}

Table 5 revealed that there was no significant difference in the job satisfaction of literacy facilitators in Nigeria and South Africa. It was observed that the t-Calculated value was less than $\mathrm{t}$-Critical values $(\mathrm{t}-\mathrm{Cal}=.432<\mathrm{t}$-Crit $=1.960),(\mathrm{P}>0.05)$. This implies that there is no significant difference. While there is a slight mean difference as South Africa got a high mean value of 59.50 than Nigeria's mean value of 58.76. However, it can be concluded that there was no statistically significant difference in the job satisfaction of literacy facilitators in the two countries.

\section{Conclusion Observations}

\subsection{Discussion}

The study revealed that adult literacy facilitators' job satisfaction in Nigeria and South Africa is at the average level. Results of this study showed that literacy facilitators in the two countries have a high level of satisfaction with the level of collegiality and team spirit they have with regard to colleagues, general work relationships with stakeholders, experience, compatibility with the job, positive feedback from supervisors, and freedom of decision to perform role as literacy facilitators. They are, however, not satisfied with issues related to salary and available facilities in the literacy centre. This result lends credence to the findings of Nnadi (2016) that literacy facilitators operate in an unconducive learning environment and lack adequate reward systems, required teaching resources, in-service training programmes and that they are been 
sidelined in the decision-making process. These may have contributed to the facilitators' ineffectiveness and poor performance which ultimately affect literacy promotional efforts and the high rate of illiterate population in Africa (Nnadi, 2016). Emmanuel and Akonor's (2017) study show that workers are more likely to give their best performance when satisfied with their remuneration. This enhances their motivation and gives them a sense of security. On the other hand, when workers remunerations are discouraging, they tend to underperform. This result also corroborates previous research findings of Mbah (2014), Efe and Obiagelli (2016) and Nakpodia (2011).

The result of this study also revealed that improvement in infrastructural facilities, facilitators' contribution to content planning and general management of the literacy centre as well as promotion of good interpersonal relations among all stakeholders in the literacy centre are major ways of improving job satisfaction level of the facilitators. This result is consistent with the submission of Teixeira, Amoroso and Gresham (2017) that infrastructural facilities like conducive classrooms, laboratories, reading materials, and equipment are crucial elements of the learning environment. A high-quality infrastructure enhances better instruction, improves learner's learning outcomes, and reduces attrition rates, among other benefits (Teixeira, Amoroso and Gresham, 2017). Also, this result resonates with the assertion made by Mbah (2014) that to improve adult literacy delivery, a conscious effort must be made to enhance facilitators' capabilities through adequate training, proper supervision, and right incentives. It was further stated that adequate infrastructures, facilities, instructional materials and required resources must be provided to enhance the effective operation of adult literacy centres (Mbah, 2014).

The result of the study further revealed that there is a joint contribution of age, gender, qualification, year of services, nature of service, marital status, and ownership of literacy centres on job satisfaction of literacy facilitators in the two countries. This implies that the demographic characteristics of the facilitators jointly predict their job satisfaction level. On a relative scale, while academic qualification, ownership type of literacy centre and age have a significant relationship to job satisfaction of facilitators, sex, year of services, nature of service and marital status have no significant relative contribution to their job satisfaction. The reason academic qualification, ownership of literacy centre and age have a significant positive relationship to job satisfaction of literacy facilitators is not far-fetched. The higher the academic achievement of an individual, the more the value they placed on education and the more the 
propensity to help those who are at the lower level of the educational ladder to attain a basic level of education (Murunga, 2019). Also, ownership type of literacy centres plays a significant role as those that were government owned hardly get the right attention because of the low priority accorded adult literacy compared to those championed by a non-governmental organization and international development partners. The NGOs understand the critical needs of literacy education and put forth significant effort and resources to make learning worthwhile for their learners and the facilitators. Equally, age plays a significant factor in the job satisfaction of an employee; it was observed that older workers tend to be more satisfied with their jobs than younger workers partly due to their having had long career in the job (Burks, n.d).

Lastly, the study revealed that there was no significant difference in the job satisfaction of literacy facilitators in Nigeria and South Africa as facilitators' responses in the two countries indicated they have similar work experience and satisfaction levels. Though South African facilitators have a slight high mean score than Nigeria's, the difference is not significant. This high mean value recorded for South African's facilitators could be because of better coordination of literacy centres by the regulating authority in South Africa compared to Nigeria where such coordination needs to be braced up.

\subsection{Conclusion}

This study has shown that adult literacy facilitators' job satisfaction level in Nigeria and South Africa is at average. The facilitators indicated that provision of a positive working environment, promotion of active contribution to content planning and general management of the literacy centre by facilitators as well as promotion of good interpersonal relations among all stakeholders in the literacy centre are the best ways to the improve job satisfaction of literacy facilitators. It also established that there is a joint contribution of age, gender, qualification, year of services, nature of service, marital status and ownership type of literacy centre on job satisfaction of literacy facilitators in the two countries. While academic qualification, ownership type of literacy centre and age have a significant relative contribution to job satisfaction of facilitators, sex, year of services, nature of service and marital status have no significant relative contribution to facilitators' job satisfaction. A comparative assessment of facilitators' job satisfaction between Nigeria and South Africa shows that there was no significant statistical difference in the job satisfaction of literacy facilitators in the two countries. The conclusion from the study is therefore that conscious effort must be made at 
mapping out strategies to improve literacy facilitators' job satisfaction to enhance adult literacy delivery in the two countries.

\section{$5.3 \quad$ Recommendations}

Based on the findings of this study, the following recommendations are made:

1. There must be a total overhauling of facilities in adult literacy centres in the two countries and facilitators must be well remunerated.

2. Facilitators must be given adequate professional training and must be promoted as at when due to enhance their career advancement.

3. Facilitators must be actively involved in content planning and general management of literacy centres.

4. Consideration must be given to educational qualification and age during facilitators' recruitment for their potentials to be fully utilized.

5. NGOs, CBOs and International Development Partners must be empowered and encouraged to play an increasing role in adult literacy provision and delivery.

6. The government in the two countries must give adult literacy education its deserved priority and invest heavily in it to achieve the Sustainable Development Goals.

\section{Author contribution}

- Sunday Itasanmi: study design, data collection, statistical analysis, data interpretation, and manuscript preparation and review

- Morakinyo Akintolu: study design, data collection, statistical analysis, and manuscript preparation

- $\quad$ Mathew T. Oni: data interpretation, \& manuscript preparation and review

\section{References}

Addae, D. (2016). Methods of teaching adult learners: a comparative study of adult education programmes in Ghana and South Africa. Retrieved from http://uir.unisa.ac.za/bitstream/handle/10500/23386/ADDAE UIR Thesis.pdf - Adobe Acrobat Pro.pdf?isAllowed=y\&sequence $=1$. 
Aitchison, J. (2003). Struggle and compromise: a history of South African adult education from 1960 to 2001. Journal of Education, 29, 125-178. https://core.ac.uk/download/pdf/83123794.pdf.

Akinwale, O. E., and George, O. J. (2020). Work environment and job satisfaction among nurses in government tertiary hospitals in Nigeria. Rajagiri Management Journal, 14(1), 71-92. https://doi.org/10.1108/ramj-01-2020-0002.

Aziri, B. (2011). Job satisfaction: a literature review. Management Research and Practice, 3(4), 77-86. http://mrp.ase.ro/no34/f7.pdf.

Burks, F. (n.d.). What is the relationship between job satisfaction and age? Small Business Chron.com. Retrieved from http://smallbusiness.chron.com/relationship-between-jobsatisfaction-age-12618.html.

Chieke, J. C., Madu, C. O., and Ewelum, J. N. (2017). Adult Literacy: The Nigerian Perspective. Asian Journal of Educational Research, 5(2), 72-78. Retrieved from http://www.multidisciplinaryjournals.com/wp-content/uploads/2017/04/Full-Paper-

ADULT-LITERACY-THE-NIGERIAN-PERSPECTIVE.pdf.

Efe, A. J., and Obiageli, O. R. (2016). Recreating the management and administration of adult and non-former education vis-à-vis entrepreneurship education. International Journal of Education and Evaluation, 2(1), 34-43. Retrieved from https://iiardpub.org/get/IJEE/VOL. 2 NO. 1 2016/Recreating the Management. Pdf.

Emmanuel, A., and Akonor, E. (2017). Factors affecting employee job satisfaction in private universities in sub-Saharan Africa: The case of Ghana. Journal of Economics, Management and Trade, 18(4), 1-13. https://doi.org/10.9734/jemt/2017/35501.

Herzberg, F., Mausner, B., and Snyderman, B. B. (1959). The motivation to work. New York, NY: Willey.

Mbah, B. A. (2014). Strategies for improving adult education for sustainable development in Nigeria. Journal of Education and Practice,5(28), 56-60. Retrieved from https://www.iiste.org/Journals/index.php/JEP/article/viewFile/16125/16324.

McCaffery, J., Merrifield, J., and Millican, J. (2007). Developing Adult Literacy: Approaches to Planning, Implementing and Delivering Literacy Initiatives. Crowley, Oxford: Oxfam GB. Retrieved from https://oxfamilibrary.openrepository.com/bitstream/handle/10546/115362/bk- 
developing-adult-literacy-030907-

en.pdf;jsessionid=72EC210B6DF963DA44852CDCBE01B4F3?sequence $=5$.

Miao, S., Komil ugli Fayzullaev, A., and Dedahanov, A. T. (2020). Management characteristics as determinants of employee creativity: The mediating role of employee job satisfaction. Sustainability, 12(5), 1948. https://doi.org/10.3390/su12051948.

Mishra, P. K. (2013). Job satisfaction. OSR Journal of Humanities and Social Science (IOSRJHSS), 14(5), 45-54. Retrieved from iosrjournals.org/iosr-jhss/papers/Vol14issue5/F01454554.pdf.

Murunga, G. (2019). Impact of an Educated Person in the Society. Retrieved from https://www.researchgate.net/publication/331558085_Impact_of_an_Educated_Perso n_in_the_Societyedited

Muthii, J. K. (2012). An investigation of problems facing implementation of adult literacy program in Kiganjo division of Gatundu south district in Kiambu County. Repository Home. https://ir-library.ku.ac.ke/handle/123456789/13190.

Nakpodia, E. (2011). Work environment and productivity among primary school teachers in Nigeria. African Research Review, 5(5). doi: 10.4314/afrrev.v5i5.29.

Nnadi, E. J. (2016). Motivational strategies provided for facilitators in adult literacy centres in Enugu north senatorial zone, Enugu State, Nigeria. International Journal for Innovation Education and Research, 4(6), 75-85. Retrieved from https://www.ijier.net/index.php/ijier/article/view/558.

Ocampo, M. L. (2004). A brief history of educational inequality from apartheid to the present. Stanford University. https://web.stanford.edu/ jbaugh/saw/Lizet_Education_Inequity.html.

Ololube, N. P. (2006). Teachers job satisfaction and motivation for school effectiveness: an assessment. Essays in Education, 18(9). Retrieved from https://openriver.winona.edu/eie/vol18/iss1/9.

Oxenham, J. (2004) In support of adult basic education with literacy in Indonesia, Ghana, Bangladesh, Senegal, and Côte d'Ivoire, 1977-2002, Washington, DC: World Bank. 
Oyelami, E. O., and Alokan, B. A. (2019). Determinants of literacy facilitators' job performance in South-West, Nigeria. Al-Hikmah Journal of Education, 6(2), 216-225. https://alhikmah.edu.ng/ajhir/index.php/aje_path/article/view/71/73.

Oyo State Agency for Adult and Non-formal Education. (n.d.). Oyo State Government | Official Website. https://oyostate.gov.ng/oyo-state-agency-for-adult-and-non-formaleducation/\#1496329289694-55426c36-4213.

Parvin, M. M., and Kabir, M. M. N. (2011). Factors affecting employee job satisfaction of pharmaceutical sector. Australian Journal of Business and Management Research, 1(9), 113-123. Retrieved from http://ajbmr.com/articlepdf/AJBMR_19_23i1n9a13a.pdf.

Roser, M., and Ortiz-Ospina, E. (2018). Literacy. our world in data. https://ourworldindata.org/literacy.

Sharma, R. D., and Jyoti, J. (2009). Job satisfaction of university teachers: an empirical study. Journal of Services Research, 9(2), 51-80. Retrieved from https://www.researchgate.net/publication/286142423_Job_satisfaction_of_university_t eachers_An_empirical_study.

Teixeira, J., Amoroso, J., and Gresham, J. (2017, October 3). Why education infrastructure matters for learning. Retrieved from http://blogs.worldbank.org/education/whyeducation-infrastructure-matters-learning.

UKEssays. (November 2018). The concept and definition of job satisfaction. Retrieved from https://www.ukessays.com/essays/psychology/the-concept-and-definition-of-jobsatisfaction-psychology-essay.php?vref=1.

UNESCO Institute for Statistics. (2010). Adult and youth literacy: global trends in gender parity. allAfrica.com. https://allafrica.com/download/resource/main/main/idatcs/00021459:40541bdd75c88ca 3668b22c25fe778b8.pdf.

UNESCO Institute of Statistics. (2017, April 12). Nigeria. UNESCO UIS. Retrieved April 4, 2021, from https://uis.unesco.org/en/country/ng.

UNESCO Institute of Statistics. (2017, April 12). South Africa. UNESCO UIS. https://uis.unesco.org/en/country/za. 
UNESCO. (1994). World Declaration on Education for All and Framework for Action to meet basic learning need. HUMANIUM - We make children's rights happen. https://www.humanium.org/en/wp-content/uploads/2017/03/Education_for_all.pdf.

UNESCO. (2007). Factsheet sub-Saharan Africa-strong foundations: early childhood care and education. Retrieved from https://en.unesco.org/gem-report/sites/gemreport/files/fact_sheet_ssa.pdf.

UNESCO. (2019, December 17). Literacy. UNESCO UIS. https://uis.unesco.org/en/topic/literacy.

UNESCO. (2020, January 16). Out-of-school children and youth. UNESCO UIS. https://uis.unesco.org/en/topic/out-school-children-and-youth.

United Nations. (2007, June 15). Adult literacy rate. Welcome to the United Nations. https://www.un.org/esa/sustdev/natlinfo/indicators/methodology_sheets/education/adul t_literacy.pdf.

Vroom, V. (1964). Expectancy theory of motivation. Leadership-Central.com. https://www.leadership-central.com/expectancy-theory-ofmotivation.html\#axzz343jOdFbL.

Warkineh, T. Z., Rogers, A., and Danki, T. N. (2017). Profiling adult literacy facilitators in development contexts: An ethnographic study in Ethiopia. International Review of Education, 64(1), 9-30. https://doi.org/10.1007/s11159-017-9686-6.

Yusuf, M. A., Ladan, B., Idris, U. A., and Halilu, A. (2013). Comparative study of the state of literacy in Nigeria and Cuba. European Scientific Journal, 9(19), 34-44. Retrieved from https://eujournal.org/index.php/esj/article/view/1541.

Zulu, S. (n.d.). A comparative analysis of the South Africa curriculum provision and that of Nigeria. https://www.globalacademicgroup.com/journals/approaches/A\%20Comparative\%20A nalysis\%20of\%20the\%20South\%20Africa\%20Curriculum.pdf. 